\title{
STUDIES ON MIXING TANNINIFEROUS PLANTS WITH AMMONIATED WHEAT STRAW IN BARKI SHEEP RATIONS ON DIGESTIBILITY, PERFORMANCE AND SOME BLOOD BIOCHEMICAL
}

\author{
E. S. H. El-Gohary; Hanim A. Elsheikh; A.M. Saber; A.R. Khattab and M.M. Eissa \\ Animal Production Research Institute, Agriculture Research Center, Dokki, Giza, Egypt.
}

(Received 7/6/2017, accepted 27/7/2017)

\section{SUMMARY}

$\mathrm{F}$ ive dietary treatments in three trails were conducted with Barki sheep as follows: $60 \%$ Concentrate feed mixture (CFM) and 20\% Ammoniated wheat straw ( AWS) as basic diet with 20\% Cassava (C) in T1, 20\% Prosopis juliflora (P) in T2, 20\% Acacia Saligna (A) in T3, $10 \% \mathrm{C}+10 \%$ A in T4 and $10 \%$ $\mathrm{C}+10 \% \mathrm{P}$ in $\mathrm{T} 5$. In Trial 1, Fifteen Barki rams $(43 \pm 1.85 \mathrm{~kg})$ divided into equally five treatment groups to evaluate the effect of condensed tannin sources on apparent nutrients digestibility. The results indicated that the rams fed with T3 $(20 \%$ A. Saligna $)$ at a maximum level of tannin $(8.33 \mathrm{~g} / \mathrm{Kg} \mathrm{DM})$ had a lower DMI $(9.72 \%)$ than the comparable group (T1) $(\mathrm{P}<0.05)$. Lower level of $\mathrm{CT}(3.87 \mathrm{~g} / \mathrm{Kg})$ in $\mathrm{T} 2$ diet have higher the digestibility coefficient $(\mathrm{P}>0.05)$ of $\mathrm{DM}, \mathrm{OM}, \mathrm{CP}, \mathrm{EE}$ and $\mathrm{CF}$ than that on $\mathrm{T} 1$ diet by 3.90, 3.57, 1.87, 3.16 and 1.04\%, respectively. Rumen ammonia concentrations were decreased with increasing of CT content in experimental diets (T3, T4, T1, T5 and T2, respectively). In Trial 2, Twenty five healthy Barki ewes at late pregnancy, weighing $41 \pm 2.29 \mathrm{~kg}$ at 3-5 years of age were randomly allocated into five dietary treatments to determine the milk yield and composition and some blood components changes due to tannin sources and productive performance of their offesprings. There was a significant increase $(\mathrm{P}<0.05)$ in milk yield with decreasing level of CT $(6.42 \%)$ for ewes fed $\mathrm{T} 2$ ration when compared with the $\mathrm{T} 1$ group and there is no considerable variability in milk composition traits among all groups. And no significantly differences in average live body weight (ALBW) of offesprings among the all groups. The experimental diet $\mathrm{T} 2$ and $\mathrm{T} 5$ had significant increased $(\mathrm{P}<0.05)$ total protein and globulin $(\mathrm{G})$ compared with the other experimental diets. No significant differences among different treatments regarding albumin was observed. Groups T3 and T4 have higher levels $(\mathrm{P}<0.05)$ of Urea-N and Creatinine when compared with the other groups. Values of AST and ALP were significantly higher $(\mathrm{P}<0.05)$ for the ewes in group $\mathrm{T} 3$ as compared to all groups, and the highest values of ALT were recorded $(\mathrm{P}<0.05)$ with T3. In Trial 3, Twenty-five healthy male Barki lambs after weaning, weighing $12 \pm 0.64 \mathrm{~kg}$, aged 3- 4 month divided into five groups to evaluate the effect of tannin sources on growth performance and some blood components. The lambs fed diets T2 and T5 produced totally $(\mathrm{P}<0.05)$ higher final live body weight $(29.03 \mathrm{Kg}$ and $28.16 \mathrm{Kg}$, respectively) at the end of the experimental period (90 days) compared to the other groups. The results indicate that the experimental tanniniferous plants can be incorporated up to $20 \%$ with ammoniated wheat straw without compromising the body health of the animals and the best impact of tanniniferous plants on the performance of Barki sheep was Prosopis juliflora (leaves \& twigs), Cassava and Acacia Saligna, respectively.

Keywords: Prosopis juliflora , Cassava, Acacia Saligna, digestibility, performance blood components, Barki sheep.

\section{INTRODUCTION}

Feed occupies the first place among the multiple roles of the livestock industry and its value reached about $58.3 \%$ of the total value of agricultural production requirements. The total area of feed crops reached about 2458 acres throughout the year and represent about $16 \%$ of the total crop area in 2008 (Ministry of Agriculture and Land Reclamation Egypt, 2008). Leaves proteins from Cassava, Acacia Saligna and Prosopis juliflora can be part of the proposed solutions to overcome shortage of feedstuff, especially in the newly reclaimed land (Duda and El-Ashry, 2000). Tannins are polyphenolic compounds that are present in a variety of plants which are utilized as food and feed (Shahidi and Naczk, 2003). Condensed tannins (CT), polymers of flavanol units, are the most common type of tannins found in forage legumes, trees, and shrubs (Barry and McNabb, 1999). Tannin from different plants might show different response in digestibility and methane production. (Makkar, 2003 and Guglielmelli et al., 2011). 


\section{El-Gohary et al.}

Acacia saligna is the most successful species of Acacia due to its tolerance to drought, ability to grow in salty soil, higher production of green biomass, higher crude protein content and good nutritive value (Degan et al., 1997).

In Egypt, Prosopis juliflora has distributed through the natural habitats in the coastal areas of Red Sea and northern part of Sinai. Prosopis juliflora pods promises to be an alternate feed resource for livestock with high yield $(169 \mathrm{~kg} /$ tree/year)

Cassava leaves have been used as a protein source and yield amounting 4.60 tones dry matter per hectare, it produced as by-product after root harvested (Ravindran and Rajaguru, 1988).

Mixing wheat straw with leaves of rich tannin-plant such Cassava, Acacia and Prosopis leaves may improve digestion due to diluting of tannin concentration and protein founded in these plants leaves might be help rumen microflora to more growing (Schlegel, 2015).

The objective of this study was undertaken to evaluate the effect of feeding Cassava, Acacia saligna and Prosopis juliflora (leaves \& twigs) with anhydrous ammonia treated wheat straw on performance and feed utilization efficiency and rumen fermentation characteristics of Barki sheep.

\section{MATERIALS AND METHODS}

Three trials were conducted at Borg El Arab Livestock Research Station, Animal Production Research Institute, Ministry of Agriculture.

\section{Experimental diets}

The fodder trees of Prosopis juliflora, Cassava and Acacia saligna were harvested along the subroads of the North Western Coast of Egypt near the Mediterranean Sea, west of Alexandria city, latitudes $21^{\circ}$ and $31^{\circ}$ North and longitudes $25^{\circ}$ and $35^{\circ}$ East. The sun-dried edible (leaves \& twigs as non-lignified stems) of Cassava (C), Prosopis juliflora (P) and Acacia saligna (A) fodder trees were subsequently chopped into shorter lengths $(5 \mathrm{~mm})$ in order to disallow feed selection, and mixed at different ratios with ground ammoniated wheat straw (AWS) to produce five mixed dietary rations. Concentrate feed mixture (CFM) has been used consists of $25 \%$ non-corticated cotton seed meal, $43 \%$ yellow corn, $25 \%$ wheat bran, $3.5 \%$ molasses, $2 \%$ limestone, $1 \%$ common salt and $0.5 \%$ minerals mixtures. Anhydrous ammonia was applied at the rate of $3 \%$ per ton of wheat straw (AWS) and the five dietary treatments were:

T1: $60 \%$ CFM plus $20 \%$ AWS \& $20 \%$ C.

T2: $60 \%$ CFM plus $20 \%$ AWS \& $20 \%$ P.

T3: $60 \%$ CFM plus $20 \%$ AWS \& $20 \%$ A.

T4: $60 \%$ CFM plus $20 \%$ AWS \& $10 \%$ C \& $10 \%$ A.

T5: $60 \%$ CFM plus $20 \%$ AWS \& $10 \%$ C \& $10 \%$ P.

Experimental diets were fed according to NRC (1985) allowances which were adjusted according to productive stage and was offered twice daily at 09:00 $\mathrm{h}$ and 16:00 $\mathrm{h}$ after discarding the residues of the previous day. Animals were offered clean drinking water and block minerals free choice and the experiment period were consisted of three trials as follows:

\section{Trial 1: Digestibility and nitrogen balance}

Fifteen Barki rams were used in the digestibility trial, aged between 2 to 3 years with average body weight $(\mathrm{ABW})$ of $43 \pm 1.85 \mathrm{~kg}$, were housed individually in metabolism cages randomly ( 3 rams in each) and assigned to the five dietary treatments. Daily feed intake, faeces and urine were recorded every morning. Feed and faeces was determined by drying to a constant weight in a forced air oven at $55^{\circ} \mathrm{C}$, then ground to pass a $1 \mathrm{~mm}$ screen and preserved for chemical analysis. Nitrogen balance values were mathematically calculated by subtracting (faecal $\mathrm{N}+$ urine $\mathrm{N}$ ) values from total $\mathrm{N}$ intake values. Ground samples of feeds, diets and faeces were analyzed for dry matter (DM), total ash and $\mathrm{N}$ content $(\mathrm{CP}=6.25 \times \mathrm{N})$ in feeds, faeces, and acidified urine using Micro-Kjeldahl method according to the procedures described by A.O.A.C. (1995). Neutral detergent fiber (NDF) and acid detergent fiber (ADF) analyzed according to method of Van Soest et al., (1991). Organic matter (OM) contents were calculated by difference (by subtracting ash from DM). Extractable condensed tannins (CT) in all ingredients and diets offered were estimated by Butanol-HCl method according to Makkar (2003). 


\section{Ruminal attributes}

Rumen liquor sample was collected from each rams at $4 \mathrm{hr}$. of post feeding using a stomach tube and placed in a $500 \mathrm{ml}$ glass jar within 4-5 min of sampling recorded $\mathrm{pH}$ using a portable calibrated digital $\mathrm{pH}$ meter (HANNA pH-meter, model HI 8424). Rumen fluid was filtered through a four layers of muslin cloth, acidified with $18.6 \mathrm{~N} \mathrm{H}_{2} \mathrm{SO}_{4}(0.02 \mathrm{~mL}$ per $\mathrm{mL}$ of ruminal fluid) to prevent ammonia volatilization and stored at $-20^{\circ} \mathrm{C}$ for further analysis, ammonia-N was determined according to Conway (1957) and total volatile fatty acids VFA's concentration was determined according to Eadie (1967).

\section{Trail 2: Ewes' performance and their offespring.}

Twenty five healthy Barki ewes at late pregnancy, at 3-5 years of age with average body weight of each group (five per treatment) $41 \pm 2.29 \mathrm{~kg}$ were randomly allocated into five dietary treatments according to their weights and age. All animals were kept in a semi-open shaded yard and kept under the same managerial conditions during the experimental period. Experiment period were consisted of 2 intervals, late pregnant (4 weeks pre-partum), and suckling ( 8 weeks post-partum). Offered and refused feeds were daily weighed to determine total DMI. Ewes had free access to fresh tap water during all the experimental period. Samples of feed and refusals were oven-dried at $105^{\circ} \mathrm{C}$ to determine DM content, and total DMI. Live body weight of ewes and their offspring's were recorded biweekly till weaning

During suckling period, milk yield for individual ewes was recorded twice daily at 7 am and $5 \mathrm{pm}$ weekly during the suckling period ( 8 weeks) which was estimated by weigh-suckle-weigh (WSW) (Ünal et al., 2007). From birth day, lambs were all time with their dams and fed on dam's milk up to weaning age ( 8 weeks), lambs were separated from their dams at $5 \mathrm{pm}$ on the evening proceeding the recording day. In the following morning day at $7 \mathrm{am}$, lambs were weighted and allowed to suckle their dams for 15 minutes period. Their body weights were then recorded and after finished suckling, ewes were hand milked to remove any residual milk. The difference in weight of the lamb before and after suckling plus the amount of milk by hand milking represented the amount of milk yield of the ewe and lambs separated again until $17 \mathrm{pm}$, at which time the procedure was repeated. Milk intake plus milk removed by hand milking represented daily milk yield. All lambs were weaned at 8 weeks of age.

Individual milk samples $(100 \mathrm{ml})$ from all ewes in each group were taken weekly through lactation period, it collected by hand milking of both sides of the udder and pooling samples into one sample per ewe. Milk samples were directly analyzing concentrations of fat, protein, lactose and total solid using a milk Oscan device (Mark®, 133B, N. FOSS, Electric, Den mark).

Dairy efficiency was calculated from the following equation: DE = Milk Yield (Kg)/DMI (Kg).

Milk energy values were calculated by using equation proposed by Economides (1986) as follows: Calorific value $(\mathrm{MJ} / \mathrm{L})=1.94+0.43 \mathrm{x}$ whereas: $\mathrm{x}=$ fat $\%$.

Fat corrected milk $(4 \% \mathrm{FCM})=0.4 \mathrm{x} \mathrm{M}+15 \times \mathrm{F}$, where $\mathrm{M}=$ quantity of milk in $\mathrm{kg}, \mathrm{F}=$ amount of fat in $\mathrm{kg}$.

At weaning, blood samples were taken from three ewes of each treatment before morning feeding via jugular venipuncture using sterile tube with anticoagulant, and centrifuged at $3000 \mathrm{rpm}$ for 20 minutes to obtained plasma and frozen at $-20{ }^{\circ} \mathrm{C}$ for late biochemical assay. The concentration values of total protein, albumin, creatinine and urea-N and the activities of the enzymes aspartate aminotransferase (AST), alanine aminotransferase (ALT), and alkaline phosphatase (ALP) were determined by spectrophotometer using commercial bio-Merioux kits (France). Globulin values were mathematically calculated by subtracting albumin values from total protein values.

\section{Trial 3: Lamb growth performance}

Twenty-five healthy male Barki lambs after weaning, weighing $12 \pm 0.64 \mathrm{~kg}$ and aged 2-3 months were divided into 5 treatment groups, the same of 5 previous mentioned dietary treatments of their mothers' treatment groups with 5 lambs in each according to the initial body weight and lasted for 90 days. The diets and fresh water were offered ad libitum for lambs. The residue of feed was collected daily then weighed before morning feeding and the diets offered at 8 a.m. daily. Lambs were weighed before the start of the study and their body weights were recorded at 15-day intervals at 8 a.m. after withhold food for 14 hours until the end of the trial. Dry matter intake of feed material, average daily gain and feed efficiency were estimated for each treatment whereas: Feed efficiency $=\mathrm{kg}$ (live mass gain) $/ \mathrm{kg}$ (feed DMI).

\section{Blood samples}

On the last day of the feeding trial, blood samples were taken from three animals of each treatment before morning feeding via jugular venipuncture using sterile tube with anticoagulant. Blood samples 


\section{El-Gohary et al.}

were centrifuged at $3000 \mathrm{rpm}$ for $20 \mathrm{~min}$ to obtained plasma and stored $-20{ }^{\circ} \mathrm{C}$ until subsequent biochemical assay. The concentration of total protein, albumin, creatinine and urea-N and the activities of enzymes aspartate aminotransferase (AST), alanine aminotransferase (ALT), and alkaline phosphatase (ALP) were determined by spectrophotometer using commercial bio-Merioux kits (France). Globulin values were mathematically calculated by subtracting albumin values from total protein values.

\section{Statistical analysis}

Statistical analysis was carried out using SAS (2003) and Duncan's multiple range Test (Duncan, 1955) was used to separate the means when the main effect was significant.

\section{RESULTS AND DISCUSSION}

\section{Chemical compositions of diets:}

The Chemical analyses of experimental feed stuffs are presented in Table (1) and calculated chemical compositions of the formulated diets are presented in Table (2). The dietary DM, OM, CF, EE, Ash, NDF and $\mathrm{ADF}$ were comparable in nutrient content, except the contents of CP decreased by 6.34, 9.67, 4.84 and $3.20 \%$ in the diets T2, T3, T4 and T5, respectively when compared to T1. This decrease is due to the higher protein content of Cassava compared to Prosopis juliflora and Acacia saligna (leaves \& twigs).

Table (1): Chemical analysis (\% on DM basis) of experimental feed stuffs.

\begin{tabular}{lccccc}
\hline Item & \multicolumn{5}{c}{ feedstuffs } \\
\cline { 2 - 6 } & CFM & AWS & C & P & A \\
\hline Dry matter, DM & 91.20 & 96.12 & 46.32 & 68.39 & 54.69 \\
Organic matter, OM & 93.90 & 90.95 & 88.46 & 93.30 & 91.46 \\
Crude protein, CP & 15.70 & 9.86 & 22.63 & 17.52 & 14.96 \\
Crude fiber, CF & 14.23 & 45.23 & 28.05 & 30.70 & 31.23 \\
Ether extract, EE & 3.13 & 1.90 & 4.92 & 3.32 & 1.97 \\
Nitrogen free extract, NFE & 60.84 & 33.96 & 32.86 & 41.76 & 43.30 \\
Ash & 6.10 & 9.05 & 11.54 & 6.70 & 8.54 \\
Neutral Detergent Fiber, NDF & 39.34 & 70.32 & 43.36 & 47.41 & 43.57 \\
Acid Detergent Fiber, ADF & 17.30 & 42.22 & 29.29 & 37.69 & 28.95 \\
Condensed Tannin, CT (g/kg DM) & $* *$ & $* *$ & 38.04 & 19.34 & 41.67 \\
\hline
\end{tabular}

$* *=$ Not detected

CFM: Concentrate Feed Mixture, AWS:- Ammoniated wheat straw, C:- Cassava, P:- Prosopis juliflora and A:Acacia Saligna

Table (2): Calculated chemical composition (\% on DM basis) of the experimental diets.

\begin{tabular}{lccccc}
\hline Item & \multicolumn{5}{c}{ Experimental diets } \\
\cline { 2 - 5 } & $\mathrm{T} 1$ & $\mathrm{~T} 2$ & $\mathrm{~T} 3$ & $\mathrm{~T} 4$ & $\mathrm{~T} 5$ \\
\hline Dry matter, DM & 83.21 & 87.62 & 84.88 & 84.05 & 85.42 \\
Organic matter, OM & 92.22 & 93.19 & 92.82 & 92.52 & 92.71 \\
Crude protein, CP & 15.92 & 14.91 & 14.38 & 15.15 & 15.41 \\
Crude fiber, CF & 23.19 & 23.72 & 23.83 & 23.51 & 23.46 \\
Ether extract, EE & 3.24 & 2.92 & 2.65 & 2.95 & 3.08 \\
Nitrogen free extract, NFE & 49.87 & 51.64 & 51.96 & 50.91 & 50.76 \\
Ash & 7.78 & 6.81 & 7.18 & 7.48 & 7.29 \\
Neutral Detergent Fiber, NDF & 46.94 & 45.15 & 47.38 & 47.06 & 46.75 \\
Acid Detergent Fiber, ADF & 25.18 & 24.26 & 25.61 & 25.35 & 24.82 \\
Condensed Tannin, CT (g/kg DM) & 7.61 & 3.87 & 8.33 & 7.97 & 5.02 \\
\hline T1:- 60\% CFM plus 40\% AWS \& C (50:50). T2:- 60\% CFM plus 40\% AWS \& P (50:50). T3:- 60\% CFM plus 40\% \\
AWS \& A (50:50). T4:- 60\% CFM plus 40\% AWS \& C \& A (50:25:25), T5:- 60\% CFM plus 40\% AWS \& C P \\
(50:25:25).
\end{tabular}

All experimental diets had a CP content above the minimum microbial requirement (7\%) to support acceptable ruminal microbial activity and the maintenance requirement of $\mathrm{CP}$ for the host ruminant (McDonald et al., 2002). 
Contents of NDF and ADF were increased in T3, T4, T1 compared with T5 and T2. Higher contents of NDF and ADF in the diets correlated with the high levels of tannin interpreted by Makkar et al., (1995) who indicated that the major difficulty encountered in fiber analysis of tannin-containing feeds using the detergent method is the presence of tannin-protein complexes. These complexes are insoluble and can appear in the fiber fraction during analysis which taken together. The condensed tannin, (CT) content (g $\mathrm{kg}-1 \mathrm{DM}$ ) varied widely from 8.33 to 3.87 , with the highest for T3 and lowest for T2.

\section{$1^{\text {st }}$ trial: Intake and digestibility}

Data of intake, digestibility and nitrogen balance are presented in Table (3). There was a negative linear relation between CT concentration and total DM intake (g/h/d). The rams fed T3 (20\% A. saligna) at a maximum level of tannin $(8.33 \mathrm{~g} / \mathrm{Kg} \mathrm{DM})$ had a lower DMI $<(9.72 \%)$ than the comparable group (T1) $(\mathrm{P}<0.05)$.

Table (3): Intake, digestibility, nutritive value and nitrogen balance of experimental diets.

\begin{tabular}{|c|c|c|c|c|c|c|}
\hline \multirow{2}{*}{ Item } & \multicolumn{5}{|c|}{ Experimental groups } & \multirow{2}{*}{$\pm \mathrm{SE}$} \\
\hline & $\mathrm{T}_{1}$ & $\mathrm{~T}_{2}$ & $\mathrm{~T}_{3}$ & $\mathrm{~T}_{4}$ & $\mathrm{~T}_{5}$ & \\
\hline DM intake (g/day) & $957.68^{\mathrm{a}}$ & $975.48^{\mathrm{a}}$ & $864.62^{\mathrm{c}}$ & $898.41^{b}$ & $962.09^{\mathrm{a}}$ & 6.513 \\
\hline \multicolumn{7}{|c|}{ Digestion coefficients (\%) } \\
\hline Dry matter, DM & 66.60 & 69.20 & 66.33 & 66.52 & 67.57 & 0.904 \\
\hline Organic matter, OM & 68.85 & 71.31 & 68.31 & 68.43 & 69.24 & 1.835 \\
\hline Crude protein, $\mathrm{CP}$ & 66.92 & 68.17 & 66.41 & 66.61 & 67.54 & 0.749 \\
\hline Ether extract, EE & 73.43 & 75.75 & 72.58 & 73.03 & 74.56 & 0.998 \\
\hline Crude fiber, $\mathrm{CF}$ & $53.70^{\mathrm{ab}}$ & $54.26^{\mathrm{a}}$ & $51.23^{\mathrm{b}}$ & $52.51^{\mathrm{ab}}$ & $53.90^{\mathrm{a}}$ & 0.759 \\
\hline $\begin{array}{l}\text { Neutral detergent } \\
\text { fiber, NDF }\end{array}$ & $65.84^{\mathrm{ab}}$ & $67.03^{\mathrm{a}}$ & $63.76^{\mathrm{b}}$ & $65.23^{\mathrm{ab}}$ & $65.91^{\mathrm{ab}}$ & 0.769 \\
\hline $\begin{array}{l}\text { Acid detergent fiber, } \\
\text { ADF }\end{array}$ & $61.12^{\mathrm{bc}}$ & $62.58^{\mathrm{a}}$ & $60.15^{\mathrm{c}}$ & $61.09^{\mathrm{bc}}$ & $61.81^{\mathrm{ab}}$ & 0.410 \\
\hline \multicolumn{7}{|c|}{$\mathrm{N}$ utilization $(\mathrm{g} / \mathrm{h} / \mathrm{d})$} \\
\hline $\mathrm{N}$ intake, $\mathrm{NI}$ & $24.39^{\mathrm{a}}$ & $23.27^{\mathrm{ab}}$ & $19.89^{c}$ & $21.78^{\mathrm{b}}$ & $23.72^{\mathrm{a}}$ & 0.569 \\
\hline $\mathrm{N}$ output & $21.50^{\mathrm{a}}$ & $20.02^{\mathrm{ab}}$ & $17.15^{\mathrm{c}}$ & $19.00^{\mathrm{b}}$ & $20.68^{\mathrm{ab}}$ & 0.548 \\
\hline $\mathrm{N}$ balance, $\mathrm{NB}$ & $2.89^{\mathrm{b}}$ & $3.25^{\mathrm{a}}$ & $2.74^{\mathrm{b}}$ & $2.78^{\mathrm{b}}$ & $3.04^{\mathrm{ab}}$ & 0.089 \\
\hline \multicolumn{7}{|c|}{ Nutritive value } \\
\hline TDN (\%) & $66.47^{\mathrm{b}}$ & $69.22^{\mathrm{a}}$ & $65.81^{\mathrm{b}}$ & $66.00^{\mathrm{b}}$ & $67.06^{\mathrm{ab}}$ & 0.834 \\
\hline $\operatorname{DCP}(\%)$ & $10.65^{\mathrm{a}}$ & $10.17^{\mathrm{ab}}$ & $9.55^{\mathrm{b}}$ & $10.09^{\mathrm{ab}}$ & $10.41^{\mathrm{ab}}$ & 0.255 \\
\hline
\end{tabular}

Reduced DMI is thought to be caused by three main mechanisms have been suggested to explain the negative effects of high tannin concentrations on voluntary feed intake: a reduction in feed palatability (McLeod, 1974) which could to due to the astringent taste resulting in feed avoidance (Kumar and Singh, 1984), the slowing of digestion, and the development of conditioned aversions (Mueller-Harvey, 2006).

Lower level of CT $(3.87 \mathrm{~g} / \mathrm{Kg})$ in $\mathrm{T} 2$ increased the digestibility coefficients $(\mathrm{P}>0.05)$ of DM, OM, CP, $\mathrm{EE}$ and $\mathrm{CF}$ than those on $\mathrm{T} 1$ by $3.91,3.57,1.87,3.16$ and $1.04 \%$, respectively. Because tannins are capable to binding with dietary proteins which makes it less degradable in the rumen (Min et al., 2003). This Negative effect of CT on nutrients digestibility was consistent with Hassanat and Benchaar (2013) who observed that condensed tannins have the ability to reduce the digestibility of organic matter in the rumen. These results accord with several studies on the influence of tannin on nutrient utilization by ruminants (Komolong et al., 2001).

In the present investigation, condensed tannins concentration in T3 suppressed NDF and ADF digestibility $(\mathrm{P}<0.05)$ by $3.16 \%$ for NDF and $1.59 \%$ for ADF than the comparable group (T1). This suggests that condensed tannins also have been shown to decrease digestion of cellulose by inhibiting endoglucanase activity of cellulolytic bacteria (McSweeney et al., 2001) and ruminal fungi (McAllister et al., 1994). The reduced fiber digestion was associated with shift in total VFA concentration in ruminal fluid.

Significant differences in $\mathrm{N}$ intake $(\mathrm{P}<0.05)$ were observed in our study, which was a reflection of differences in DM intake and differences in protein contents of treatment tanniniferous plants that due to the slightly higher $\mathrm{N}$ content of the Cassava compared with the Prosopis juliflora and the Acacia 


\section{El-Gohary et al.}

saligna. Therefore, the $\mathrm{N}$ intake was larger with the Cassava diet (T1) than with Prosopis juliflora (T2) and Acacia saligna (T3), respectively. Moreover, animals in all groups still maintained a positive $\mathrm{N}$ balance and their live weight. However, the higher NB $(\mathrm{P}<0.05)$ of rams on T2 group $(3.25 \mathrm{~g} / \mathrm{h} / \mathrm{d})$ compared $(\mathrm{P}<0.05)$ with T1 (2.89), T3 (2.74) and T4 (2.78). This could be described by the formation of tannins complexes with some digestive enzymes (trypsin and amylase) to form inactive complexes or with proteins and carbohydrates are inaccessible to microorganisms in lower gut which inhibit the digestive enzymes (Silanikove et al., 1994). Highest values of $\mathrm{N}$ output were observed in $\mathrm{T} 1$ with significant differences $(\mathrm{P}<0.05)$ compared to $\mathrm{T} 3$ which could be due to the slightly higher $\mathrm{N}$ content of the Cassava compared with the Prosopis juliflora and the Acacia saligna, respectively.

Total digestible nutrients (TDN) values of T2 was greater $(69.22 \%)$ than for all groups $(\mathrm{P}<0.05)$. However, the lowest digestible crude protein $(\mathrm{P}<0.05)$ values $(9.55 \%)$ was noticed with T3 compared $(\mathrm{P}<0.05)$ with $\mathrm{T} 1$ group. This could be due to the slightly lower $\mathrm{N}$ content of the Acacia saligna compared with the N content of Cassava and Prosopis juliflora .

\section{Ruminal fermentation}

Data in Table (4) showed that, the average rumen ammonia concentration significantly $(\mathrm{P}<0.05)$ lower in $\mathrm{T} 3$ and $\mathrm{T} 4$, while was significantly $(\mathrm{P}<0.05)$ higher in $\mathrm{T} 2$. Rumen ammonia concentrations were decreased with increasing CT content in experimental diets (T3, T4, T1, T5 and T2, respectively). In all groups, the maximum ammonia concentrations exceeded the level considered the minimum required to maximize microbial growth (Satter and Slyter, 1974). In general, the reduction in rumen ammonia with increased CT content is associated with lower protein degradation, mainly through the formation of tannin-protein complexes that are minimally degraded by ruminal microbes (Molan et al., 2001) and greater non-ammonia nitrogen flow to the duodenum (Waghorn, 1996). These complexes formed between tannins and proteins or other compounds are generally unstable (Kumar and Singh, 1984).

Table (4): Ammonia concentrations, total volatile fatty acids and $\mathrm{pH}$ of ruminal fluid of sheep fed different experimental diets.

\begin{tabular}{lcccccc}
\hline \multirow{2}{*}{ Item } & \multicolumn{5}{c}{ Experimental groups } \\
\cline { 2 - 6 } & $\mathrm{T} 1$ & $\mathrm{~T} 2$ & $\mathrm{~T} 3$ & $\mathrm{~T} 4$ & $\mathrm{~T} 5$ \\
\hline $\mathrm{pH}$ & 6.18 & 5.95 & 6.22 & 6.19 & 6.05 & 0.079 \\
$\mathrm{NH} 3-\mathrm{N}(\mathrm{mg} / 100 \mathrm{ml})$ & $5.81^{\mathrm{c}}$ & $5.75^{\mathrm{a}}$ & $5.28^{\mathrm{d}}$ & $5.39^{\mathrm{d}}$ & $6.38^{\mathrm{b}}$ & 0.077 \\
Total volatile fatty acids $(\mathrm{mM} / 100 \mathrm{ml})$ & $6.98^{\mathrm{b}}$ & $7.67^{\mathrm{a}}$ & $6.15^{\mathrm{c}}$ & $6.64^{\mathrm{b}}$ & $7.53^{\mathrm{a}}$ & 0.143 \\
\hline a,b,c and $^{d}:$ Means denoted within the same row with different superscripts are significantly different at $P<0.05$.
\end{tabular}

Concentration of total volatile fatty acids $($ TVFA's) was significantly $(\mathrm{P}<0.05)$ higher with feed T2 and T5. In the contrary, TVFA's was lower $(\mathrm{P}<0.05)$ significantly with groups fed T3, T4 and T1. Parallel results were obtained by (McSweeney et al., 2001) who observed that improved microbial protein synthesis and reduced protein degradation as decreased branched-chain VFA is commonly observed when protein degradation is reduced by tannins. Hassanat and Benchaar (2013) who observed CT have the ability to reduce the fermentation and digestibility of organic matter in the rumen, they also alter the proportions of VFA's the presence of CT may reduce the NH3 production in the rumen.

\section{$2^{\text {nd }}$ trial: Ewes performance.}

Results in Table (5) showed that variation in tannin level has effect on daily DM intake during milk production in Barki ewes. The lowest values of DMI as \% of body weight were observed in T3 (3.18\%) with significantly difference $(\mathrm{P}<0.05)$. The findings are in agreement with Mueller-Harvey, (2006) who reported that addition of tannins to dairy diets usually reduces feed intake, because of reduced palatability, decreased rate of digestion and development of conditioned aversion.

Throughout eight lactation weeks during the suckling period, average weekly milk yield showed the same trend of change, where gradual increase after lambing reaching its peak at the $3^{\text {rd }}$ wk of lactation in all groups. While, it was gradually decrease till to 8 weeks of lactation. There was also a significant increase $(\mathrm{P}<0.05)$ in milk yield $(\mathrm{g} / \mathrm{h} / \mathrm{d})$ with decreasing level of $\mathrm{CT}$ with an increase of $6.42 \%$ in ewes of T2 when compared with the T1. The increasing in milk production is near to that recorded by Anantasook et al., (2014) who showed an increase of $10 \%$ in milk yield of cows fed $88 \mathrm{~g}$ of CT per $\mathrm{kg}$ DM. The same trend found in fat corrected milk, 4\% FCM yield whereas; the lowest value was observed with T3 $(714.86 \mathrm{~g} / \mathrm{h} / \mathrm{d})$ with significant differences $(\mathrm{P}<0.05)$ compared to the other groups. At this respect, similar 
results were previously observed by Maamouri et al., (2011) in ewes, who found high level of Acacia feeding significantly decreased milk production.

Table (5): Feed intake, milk yield and composition of ewes fed different experimental diets.

\begin{tabular}{|c|c|c|c|c|c|c|}
\hline \multirow[t]{2}{*}{ Item } & \multicolumn{5}{|c|}{ Experimental diets } & \multirow{2}{*}{$\pm \mathrm{SE}$} \\
\hline & $\mathrm{T}_{1}$ & $\mathrm{~T}_{2}$ & $\mathrm{~T}_{3}$ & $\mathrm{~T}_{4}$ & $\mathrm{~T}_{5}$ & \\
\hline Total DMI ,Kg/h/d & 1.483 & 1.511 & 1.303 & 1.446 & 1.503 & 0.118 \\
\hline $\mathrm{DMI}$ as $\% \mathrm{BW}$ & 3.62 & 3.69 & $3.18 \mathrm{~b}$ & 3.53 & 3.67 & 0.094 \\
\hline Milk yield, g/h/d & $551.86^{\mathrm{bc}}$ & $587.29^{\mathrm{a}}$ & $514.29^{\mathrm{d}}$ & $541.71^{\mathrm{c}}$ & $570.89^{\mathrm{ab}}$ & 6.947 \\
\hline FCM yield, $4 \%$ & $781.99^{c}$ & $841.88^{\mathrm{a}}$ & $714.86^{\mathrm{e}}$ & $759.48^{\mathrm{d}}$ & $813.23^{\mathrm{b}}$ & 6.397 \\
\hline Fat, \% & 6.78 & 6.89 & 6.60 & 6.68 & 6.83 & 0.266 \\
\hline Protein, \% & 4.86 & 4.89 & 4.72 & 4.76 & 4.88 & 0.171 \\
\hline Lactose, \% & 5.74 & 5.77 & 5.72 & 5.74 & 5.75 & 0.199 \\
\hline Total solids, $\%$ & $16.52^{\mathrm{ab}}$ & $16.94^{\mathrm{a}}$ & $16.40^{\mathrm{b}}$ & $16.47^{\mathrm{b}}$ & $16.73^{\mathrm{ab}}$ & 0.134 \\
\hline Solids not fats, SNF, \% & $9.74^{b}$ & $10.05^{\mathrm{a}}$ & $9.80^{\mathrm{b}}$ & $9.79^{\mathrm{b}}$ & $9.90^{\mathrm{ab}}$ & 0.066 \\
\hline Calorific value, $\mathrm{MJ} / \mathrm{L}$ & 4.86 & 4.90 & 4.78 & 4.81 & 4.88 & 0.063 \\
\hline $\begin{array}{l}\text { Dairy efficiency, } \mathrm{kg} \text { milk/kg } \\
\text { DMI }\end{array}$ & 0.372 & 0.389 & 0.395 & 0.375 & 0.381 & 0.011 \\
\hline
\end{tabular}

As presented in our study there is no considerable variability in milk composition traits among the all groups, whereas, a specific role for CT concentration at $3.87 \mathrm{~g} / \mathrm{DM}$ (T2) and 8.33 g/DM (T3) was unclear since the difference in milk composition (fat, protein and lactose) between the treatments was not significant, despite a trend toward lower percentages of different milk contents for ewes on the high CT content diets. In agreement with the present results, Abdalla et al., (2013) found that fat percentage in goat milk was not affected by type of roughages. Also, El-Saadany et al., (2016) cleared that there was a non-significant tendency of decrease in fat content in ewes milk fed Cassava as compared to other groups during all lactation weeks.

These results suggest that decreased total VFA productions in the rumen and digestion coefficients of all nutrients and the subsequently decreased availability of VFA and nutrients in the small intestine with feeding high CT may be responsible for decreasing milk yield traits in this study. In addition, T2 had the greatest values $(\mathrm{P}<0.05)$ of total solids $(\mathrm{TS})$ and solids not fats $(\mathrm{SNF}) \%$ compared the other treatments. This results in line with that observed by, El-Saadany et al., (2016) who found TS content was significantly $(\mathrm{P}<0.05)$ lower in milk of ewes fed Cassava diet than in other groups (Acacia - Atriplex) during the $1^{\text {st }}$ six weeks of lactation.

No significant differences were observed in dairy efficiency ( $\mathrm{kg}$ milk/kg DMI) and calorific value $(\mathrm{MJ} / \mathrm{L})$ in this study. Apparently; these inconsistent findings are probably related to ruminant species, physiological stage and type of CT and dose.

\section{Performance of offspring's:}

As presented in our study Table (6), there is no considerable variability in average live body weight among all experimental groups from birth till weaning and the differences were not significant.

As shown in Fig. (1), it's worth noting that total gain and average daily gain of lambs (males and females) was not affected at different ages affected by their mothers feeding shrubs plants. These results agreement with Shetaewi et al. (2001), Fasae et al.(2015) and El-Saadany et al. (2016). This means that feeding ewes during pre- and postpartum period on different forage types in this study was save without adversely effects on growth performance of lambs produced. 


\section{El-Gohary et al.}

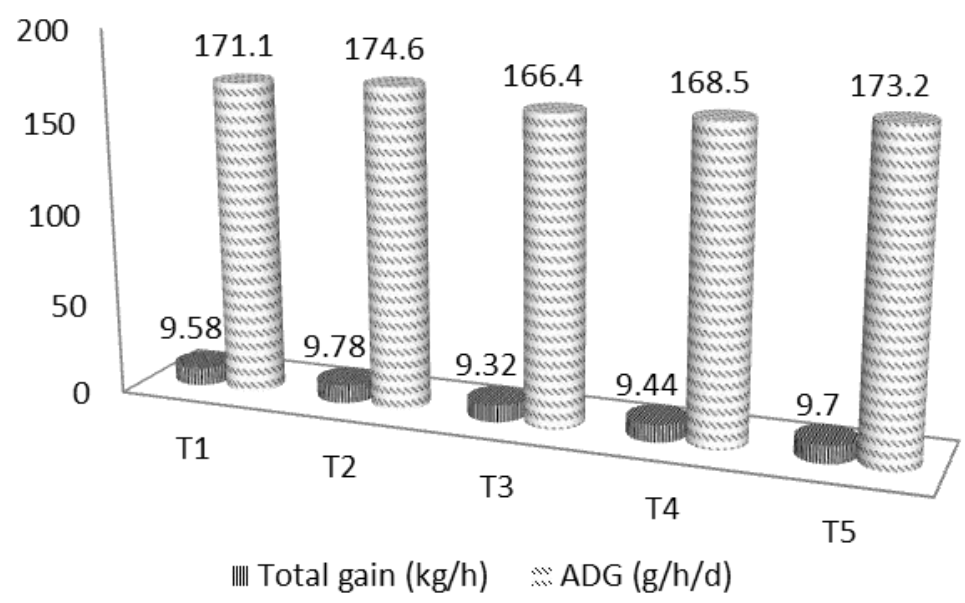

Fig. (1): Average LBW of lambs from ewes in the experimental groups.

\section{Ewes blood parameters:}

Table (6) shows that, $\mathrm{T} 2$ and $\mathrm{T} 5$ had significant $(\mathrm{P}<0.05)$ higher values of total protein and Globulin (G) compared with the other treatments. No significant difference among different treatments regarding Albumin (A) was observed. Increased total protein and its fractions could be attributed to the increase in digestibility of CP (Shahen et al., 2004).

Groups T3 and T4 have higher levels $(\mathrm{P}<0.05)$ of urea- $\mathrm{N}$ and creatinine when compared with the other groups. Urea is a toxic end product of protein catabolism, yet rumen flora can utilize its nitrogen for microbial protein synthesis and increases its concentration may produce toxic effect (Aldoori et al., 2011).

Table (6): Some blood biochemical parameters of Barki ewes fed different experimental diets.

\begin{tabular}{|c|c|c|c|c|c|c|}
\hline \multirow{2}{*}{ Item } & \multicolumn{5}{|c|}{ Experimental treatments } & \multirow{2}{*}{ \pm S.E } \\
\hline & $\mathrm{T} 1$ & $\mathrm{~T} 2$ & $\mathrm{~T} 3$ & $\mathrm{~T} 4$ & T5 & \\
\hline \multicolumn{7}{|l|}{ Protein fraction } \\
\hline Total protein, g/dl & $7.82^{\mathrm{b}}$ & $8.59^{\mathrm{a}}$ & $7.41^{\mathrm{b}}$ & $7.72^{\mathrm{b}}$ & $8.47^{\mathrm{a}}$ & 0.181 \\
\hline $\operatorname{Albumin}(\mathrm{A}), \mathrm{g} / \mathrm{dl}$ & 2.65 & 2.81 & 2.40 & 2.48 & 2.77 & 0.127 \\
\hline Globulin $(\mathrm{G}), \mathrm{g} / \mathrm{dl}$ & $5.17^{\mathrm{b}}$ & $5.78^{\mathrm{a}}$ & $5.01^{\mathrm{b}}$ & $5.25^{\mathrm{b}}$ & $5.70^{\mathrm{a}}$ & 0.121 \\
\hline \multicolumn{7}{|c|}{ Kidney function } \\
\hline Urea-N, mg/dl & $57.32^{\mathrm{b}}$ & $54.28^{\mathrm{c}}$ & $61.88^{\mathrm{a}}$ & $60.36^{\mathrm{a}}$ & $55.44^{\mathrm{bc}}$ & 0.705 \\
\hline Creatinine $\mathrm{mg} / \mathrm{dl}$ & $0.93^{\mathrm{c}}$ & $0.81^{\mathrm{d}}$ & $1.18^{\mathrm{a}}$ & $1.06^{\mathrm{b}}$ & $0.89^{\mathrm{cd}}$ & 0.032 \\
\hline \multicolumn{7}{|c|}{ Liver function } \\
\hline AST, IU/l & $99.62^{\mathrm{b}}$ & $91.84^{\mathrm{d}}$ & $118.49^{\mathrm{a}}$ & $101.85^{\mathrm{b}}$ & $95.83^{c}$ & 0.927 \\
\hline ALT, IU/1 & $39.64^{\mathrm{ab}}$ & $37.87^{\mathrm{b}}$ & $41.19^{\mathrm{a}}$ & $40.82^{\mathrm{a}}$ & $38.72^{b}$ & 0.634 \\
\hline ALP, IU/1 & $53.01^{\mathrm{b}}$ & $42.76^{\mathrm{d}}$ & $59.77^{\mathrm{a}}$ & $55.99^{\mathrm{b}}$ & $48.91^{\mathrm{c}}$ & 1.097 \\
\hline
\end{tabular}

Values of AST and ALP, IU/1 were significantly higher $(\mathrm{P}<0.05)$ for the ewes in T3 as compared to all groups, also the highest values of ALT were recorded $(\mathrm{P}<0.05)$ with T3 and T4. Overall mean of kidney function and liver function values are in the normal range according to Fasae et al., (2015).

\section{$3^{\text {rd }}$ trial: Lamb growth performance:}

Effect of experimental diets on subsequent growth performance traits of Barki lambs are presented in Table (7). As illustrated in fig (2) and Table (7), regardless of dietary treatment, all animals maintained live body weight in this trial whereas, the lambs of $\mathrm{T} 2$ and $\mathrm{T} 5$ produced totally $(\mathrm{P}<0.05)$ higher final live body weight (29.03 and $28.16 \mathrm{Kg}$, respectively) compared to the other groups. 
The significantly $(\mathrm{P}<0.05)$ higher values of growth rate were observed for lambs in T2 $(186.55 \mathrm{~g} / \mathrm{d})$ and T5 $(179.33 \mathrm{~g} / \mathrm{d})$ and obtained higher $(\mathrm{P}<0.05)$ total gain $(16.79$ and $16.14 \mathrm{Kg}$, respectively) compared to the other experimental groups. Similar effects were observed in sheep and goats fed fresh or dried A. salicini, as shrub with a high CT content (Degen et al., 1997). These findings are also in accordance with study of Abdullah et al., (2011) who observed increased body weight when the basal diet (elephant grass) for Omani sheep was supplemented with Prosopis juliflora pods.

Table (7): Some growth characteristics, daily feed intake, feed conversion and feed efficiency in Barki lambs under different treatments.

\begin{tabular}{|c|c|c|c|c|c|c|}
\hline \multirow[t]{2}{*}{ Item } & \multicolumn{5}{|c|}{ Experimental groups } & \multirow{2}{*}{ \pm S.E. } \\
\hline & $\mathrm{T}_{1}$ & $\mathrm{~T}_{2}$ & $\mathrm{~T}_{3}$ & $\mathrm{~T}_{4}$ & $\mathrm{~T}_{5}$ & \\
\hline Initial weight, (kg ) & 12.28 & 12.24 & 12.30 & 12.27 & 12.02 & 0.124 \\
\hline Final weight, ( kg) & $26.91^{\mathrm{b}}$ & $29.03^{\mathrm{a}}$ & $26.4^{\mathrm{b}}$ & $26.56^{\mathrm{b}}$ & $28.16^{\mathrm{a}}$ & 0.309 \\
\hline Total gain, $(\mathrm{kg})$ & $14.63^{\mathrm{c}}$ & $16.79^{\mathrm{a}}$ & $14.10^{\mathrm{d}}$ & $14.29^{\mathrm{cd}}$ & $16.14^{\mathrm{b}}$ & 0.128 \\
\hline Growth rate (g per day) & $162.55^{\mathrm{c}}$ & $186.55^{\mathrm{a}}$ & $156.66^{\mathrm{d}}$ & $158.78^{\mathrm{cd}}$ & $179.33^{\mathrm{b}}$ & 1.236 \\
\hline \multicolumn{7}{|c|}{ Daily feed intake: } \\
\hline Total DMI (g/h/d) & $709.34^{\mathrm{a}}$ & $724.29^{\mathrm{a}}$ & $683.06^{\mathrm{b}}$ & $683.41^{b}$ & $721.23^{\mathrm{a}}$ & 5.479 \\
\hline $\mathrm{DMI}$ as $\% \mathrm{BW}$ & 3.62 & 3.51 & 3.53 & 3.52 & 3.59 & 0.085 \\
\hline CP intake, $(\mathrm{g} / \mathrm{h} / \mathrm{d})$ & $112.93^{\mathrm{a}}$ & $107.99^{b}$ & $98.22^{\mathrm{d}}$ & $103.54^{\mathrm{c}}$ & $111.14^{\mathrm{ab}}$ & 1.268 \\
\hline Tannins intake (g/h/day) & $5.41^{\mathrm{a}}$ & $2.80^{\mathrm{c}}$ & $5.69^{\mathrm{a}}$ & $5.45^{\mathrm{a}}$ & $3.62^{\mathrm{b}}$ & 0.108 \\
\hline \multicolumn{7}{|c|}{ Feed conversion ratio: } \\
\hline (kg DMI / kg Body gain) & $4.36^{\mathrm{a}}$ & $3.88^{\mathrm{c}}$ & $4.36^{\mathrm{a}}$ & $4.30^{\mathrm{ab}}$ & $4.02^{\mathrm{cb}}$ & 0.100 \\
\hline
\end{tabular}

\section{Fig. (2):- Impact of condesed tannins on growth rate}

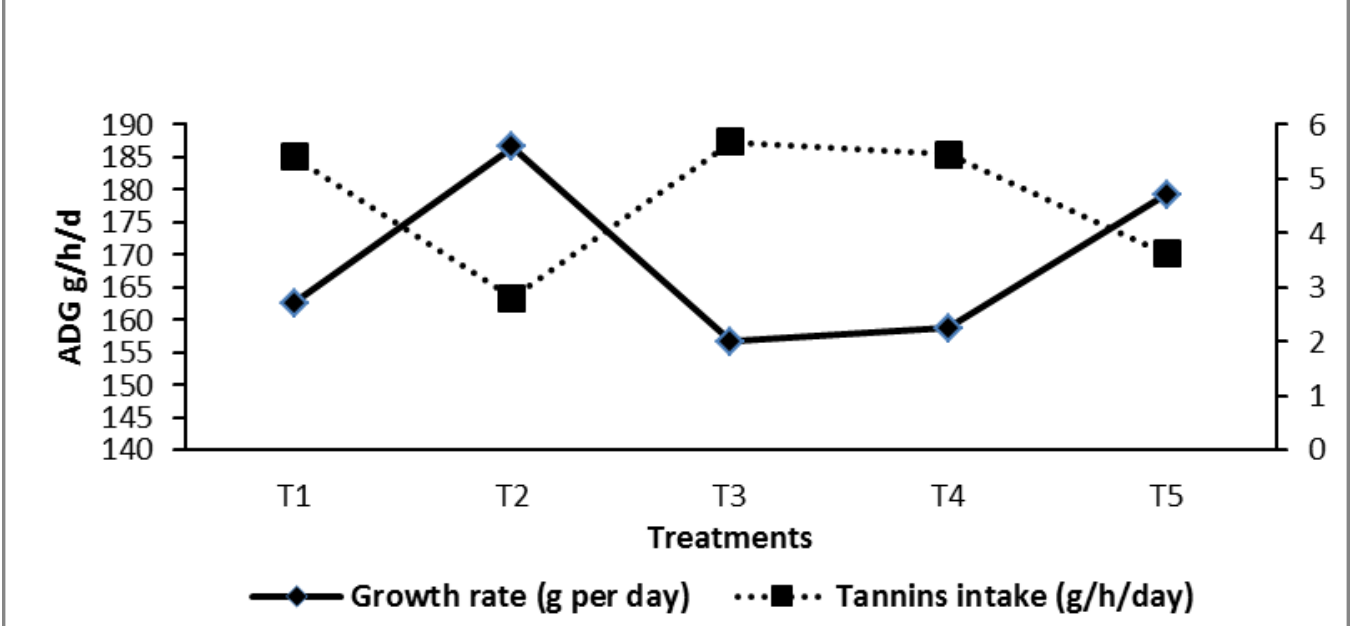

Fig. (2): Impact of condensed tannins on growth rate

This reduction in daily weight gain with increasing CT may be due to a combination of reduced voluntary feed intake and low digestibility of nutrients, attributed mainly to the high CT content (Chriyaa et al., 1997).

The lower values $(\mathrm{P}<0.05)$ of DMI were marked in lambs fed T3 $(683.06 \mathrm{~g} / \mathrm{h} / \mathrm{d})$ and T4 $(683.41 \mathrm{~g} / \mathrm{h} / \mathrm{d})$ compared to the other groups although dry matter intake $(\%)$ was not different significantly between all experimental groups. The reduction in feed intake might be due to the CT suppressed the appetite of animals to the diet as it has slowly rates of digestion in the rumen (Mahgoub et al., 2005).

Highest values of CP intake were observed with lambs in T1 $(112.93 \mathrm{~g} / \mathrm{h} / \mathrm{d})$ and T5 $(111.14 \mathrm{~g} / \mathrm{h} / \mathrm{d})$ with significant differences $(\mathrm{P}<0.05)$ compared to other experimental groups. This is attributed largely to the relatively high levels of CP in Cassava, that was consistent with (Wanapat, 2000) who found Cassava 


\section{El-Gohary et al.}

hay has been used successfully as a source of high protein roughage in lactating dairy cows. There was a significant difference in CT intake between the treatments whereas, the lowest value was observed with lambs in T2 (2.80) with significant differences $(\mathrm{P}<0.05)$ followed by T5 (3.62), T1 (5.41), T4 (5.45) and finally T3 (5.69). These could be due to the high content of CT in A. saligna (Krebs et al., 2007). On the other hand, increased significantly $(\mathrm{P}<0.05)$ feed conversion ratio (FCR) for lambs in $\mathrm{T} 2$ (3.88) as compared T1, T3 and T4 groups that could be explain by high total feed intake in this groups, which had more palatability because tannins are usually associated to a decrease in palatability, and consequently discourage grazing (Ngwa, et al., 2002). Also, high tannin levels reduce preference of plants by cattle, sheep and goats (Perevolotsky, et al., 1993).

\section{Blood biochemical parameters}

Data of blood biochemical parameters of lambs are presented in Table (8). Total protein and globulin (G) decreased linearly $(\mathrm{P}<0.05)$ but serum enzymes ALT and ALP (IU/l)), Urea-N, and creatinine were taken opposite trend and increased linearly $(\mathrm{P}<0.05)$ as the level of CT in the diet increased.

Table (8): Some blood biochemical parameters of Barki lambs fed different experimental diets.

\begin{tabular}{|c|c|c|c|c|c|c|}
\hline \multirow{2}{*}{ Item } & \multicolumn{5}{|c|}{ Experimental treatments } & \multirow{2}{*}{$\pm \mathrm{SE}$} \\
\hline & $\mathrm{T} 1$ & $\mathrm{~T} 2$ & T3 & $\mathrm{T} 4$ & T5 & \\
\hline \multicolumn{7}{|c|}{ Protein fraction } \\
\hline Total protein, g/dl & $6.51^{\mathrm{b}}$ & $7.36^{\mathrm{a}}$ & $6.46^{\mathrm{b}}$ & $6.50^{\mathrm{b}}$ & $6.79^{b}$ & 0.104 \\
\hline Albumin(A), g/dl & 2.64 & 2.87 & 2.54 & 2.58 & 2.65 & 0.109 \\
\hline Globulin $(G), g / d l$ & $3.87^{\mathrm{b}}$ & $4.49^{\mathrm{a}}$ & $3.92^{\mathrm{b}}$ & $3.92^{\mathrm{b}}$ & $4.14^{\mathrm{b}}$ & 0.105 \\
\hline \multicolumn{7}{|c|}{ Kidney function } \\
\hline Urea-N, mg/dl & $56.48^{\mathrm{ab}}$ & $51.72^{\mathrm{b}}$ & $60.79^{\mathrm{a}}$ & $57.04^{\mathrm{ab}}$ & $55.76^{\mathrm{ab}}$ & 1.605 \\
\hline Creatinine, $\mathrm{mg} / \mathrm{dl}$ & $1.58^{\mathrm{ab}}$ & $1.45^{\mathrm{b}}$ & $1.79^{\mathrm{a}}$ & $1.71^{\mathrm{a}}$ & $1.57^{\mathrm{ab}}$ & 0.067 \\
\hline \multicolumn{7}{|c|}{ Liver function } \\
\hline AST, IU/1 & 84.44 & 82.64 & 85.45 & 84.98 & 83.48 & 0.822 \\
\hline ALT, IU/l & $34.38^{\mathrm{a}}$ & $30.26^{\mathrm{b}}$ & $35.18^{\mathrm{a}}$ & $35.06^{\mathrm{a}}$ & $33.90^{\mathrm{a}}$ & 0.824 \\
\hline ALP, IU/1 & $41.23^{\mathrm{c}}$ & $33.34^{\mathrm{d}}$ & $49.35^{\mathrm{a}}$ & $44.31^{\mathrm{b}}$ & $39.89^{c}$ & 0.664 \\
\hline
\end{tabular}

No significant effect of dietary treatment $(\mathrm{P}<0.05)$ was found on albumin $(\mathrm{A})$, and AST. Condensed tannins as a plant secondary compound may affect blood parameters by maintaining them (Raghuvansi et al., 2007), decreasing (Joy et al., 2001) or increasing others (Mohammed et al., 2004).

\section{CONCLUSION}

The results from this trial suggest that low concentrations of CT increased nutrients digestibility, milk yield and growth performance as a consequence of an increase of rumen escape proteins and higher absorption of amino-acids. Dietary inclusion of leaves \& twigs of Acacia saligna Cassava and then Prosopis, respectively as a source of tannin had negative impacts on productive performance when CT level in the diet is high. The findings suggest that leaves \& twigs of Prosopis, Cassava and then Acacia Saligna, respectively can replace up to $20 \%$ dietary inclusion in the presence of relatively high concentrate meal contents in diets for Barki sheep. More research is required to determine the most appropriate ratios for the introduction of each of the experimental tanniniferous plants under different feeding strategies.

\section{REFERENCES}

Abdalla, E.B; H. A. Gawish; A. M. El-Sherbiny; N. H. Ibrahim and A.S. El-Hawy (2013). Reproductive efficiency of Damascus goats in salt-affected lands in South Sinai, Egypt. J. of American Sci., 9(8): 170-177. 
Abdullah, Y. A, S. O. Belal, M. M. Marwan, K. M. Sulaiman and A. A. Majdi (2011). Growth performance, carcass and meat characteristics of black goat kids fed sesame hulls and Prosopis juliflora Pods. Asian Aust. J. Anim. Sci., 24: 1217-1226.

Aldoori, Z. T., Aljumaily, M. H. and S. S. A. Altekrity (2011). Effect of different sources of roughages on some blood components of Awassi lambs. The Iraqi J. of Agric. Sci., 42 (4):116- 122,

Anantasook, N., M. Wanapat, A. Cherdthongand P. Gunun (2014). Effect of tannins and saponins in Samaneasamanon rumen environment, milk yield and milk composition in lactating dairy cows. J. Anim. Physiol. Nut. DOI: 10.1111/jpn.12198.

AOAC (1995). Association Analytical Chemists, Official Methods of Analysis. (16 $\left.{ }^{\text {th }}\right)$ Ed. Washington, D.C., USA.

Barry, T. N. and W. C. McNabb (1999). The implications of condensed tannins on the nutritive value of temperate forages fed to ruminants. Brit. J. Nutr., 81: 263- 272.

Chriyaa, A., K. J. Moore and S. S. Waller (1997). Intake, digestion, and nitrogen balance of sheep fed shrub foliage and medic pods as a supplement to wheat straw. Anim. Feed Sci. Technol., 65: 183-196.

Conway, E.J (1957). Micro diffusion analysis and volumetric error, 4th Ed.New York, NY: The Macmillan Co., pp 1-465.

Degan, A. A., K. Blanke, M. Becker, R. W. Kam, A. Benjamin and H. P. S. Makkar (1997). The nutritive value of Acacia Saligna for goats and sheep. Anim. Sci., 64: 253-259.

Duda, A. M. and M. T. El-Ashry (2000). Addressing the global water and environment crisis through integrated approaches to the management of land, water and ecological resources. Water Intern., 25 (1): 115-126.

Duncan, D.B (1955). Multiple range and multiple. F. Test. Biometrics, 11:1.

Eadie, M. (1967). Studies on the ecology of certain rumen ciliate protozoa. J. General Microbiology, 49: 175-194.

Economides Nicholas (1986). Advertising and maximal product differentiation, Discussion paper no. 316 (Department of Economics, Columbia University, New York, NY).

EL-Saadany, S. A., E. S. H. EL-Gohary, H. H. Omar, EL .A. EL-wakeel and I. A. EL-sayed. (2016). Impact of feeding some forage shrubs on milk, blood parameters of ewes and growth performance of their offspring's in north coast. J. Anim. and Poult. Prod., Mans. Univ., 7 (1): 47-57.

Fasae, O. A., A. O. Amos, A. Owodunni and A. O. Yusuf. (2015). Performance, hematological parameters and faecal egg count of semi-intensively managed West African dwarf sheep to varying levels of Cassava leaves and peels supplementation. Pertanika J. of Trop. Agric. Sci., 38(1) :71-81.

Guglielmelli, A., S., Calabro, R., Primi, F., Carone, M. I., Cutrignelli, R., Tudisco, G., Piccolo, B., Ronchi, and Danieli, P. P (2011). In vitro fermentation patterns and methane production of sainfoin (Onobrychisviciifolia Scop.) hay with different condensed tannin contents. Grass Forage Sci., 66:488500 .

Hassanat, F. and C. Benchaar. (2013). Assessment of the effect of condensed (Acacia and quebracho) and hydrolysable (chestnut and valonea) tannins on rumen fermentation and methane production in vitro. J. Sci. Food Agric., 93(2): 332-339.

Joy, P. P., J. Thomas, S. Mathew and B. P. Skaria (2001). Medicinal Plants. In: Bose, T.K., Kabir, J., Das, P. and Joy, P.P., Eds., Tropical Horticulture, Naya Prokash, Calcutta, 449- 632.

Krebs, G. L., D. M. Howard and K. Dods (2007). Feeding Acacia saligna to Sheep and Goats with or without the addition of urea or polyethylene glycol. Asian-Aust. J. Anim. Sci., 20(10): 1551-1556.

Komolong, M. K., D. G. Barber and D. M. McNeill (2001). Postruminal protein supply and N retention of weaner sheep fed on a basal diet of lucerne hay (Medicago sativa) with increasing levels of quebracho tannins. Anim. Feed Scie and Techno. 92: 59- 72

Kumar, R. and M. Singh (1984). Tannins: Their Adverse Role in Ruminant Nutrition. J. of Agric.. and Food Chem., 32: 447-453. 


\section{El-Gohary et al.}

Maamouri, O. N. Atti, K. Kraiem and M. Mahouchi (2011). Effects of concentrate and Acaciac yanophylla foliage supplementation on nitrogen balance and milk production of grazing ewes. Livestock Sci. 139 (3): 267-270.

Mahgoub, O. I. T. Kadim, E. H. Johnson, A. Srikakumar, N. M. Al-Saqri, A. S. Al-Abri and A. Richie (2005). The use of concentrate diet containing Meskit (Prosopis juliflora) pods and date palm byproducts to replace commercial concentrate diets of Omani sheep. Anim. Feed Sci. Technol., 120: 33 41.

Makkar, H. P. S (2003). Quantification of tannins in tree and shrub foliage. In: Makkar HPS (ed), A Laboratory Manual, Kluwer Academic Publishers, Dordrecht, The Netherlands, p. 102-107.

Makkar, H. P. S., M. Blümmel and K. Becker (1995). Formation of complexes between polyvinyl pyrrolidone and polythylene glycol with tannins and their implications in gas production and true digestibility in in vitro techniques. Br. J. Nut., 73: 897-913.

McAllister, T. A., H. D. Bae, G.A. Jones and K. J. Cheng (1994). Microbial attachment and feed digestion in the rumen. J. Anim. Sci., 72: 3004-3018.

McDonald, P., R. A. Edwards, J. F. D. Greenhalgh and C. A. Morgan (2002). Animal Nutrition, $6^{\text {th }}$ ed. Prentice Hall. New York, NY, USA. pP 544.

McLeod, M. N (1974). Plant tannins their role in forage quality. Nut. Abs. Rev., 44: 803-812.

McSweeney, C. S., B. Palmer, D. M. Mcneill and D. O. Krause (2001). Microbial interactions with tannins: nutritional consequences for ruminants. Anim. Feed Sci. Technol., 91: 83-93.

Min, B.R., Barry, T.N., Attwood, G.T and McNabb, W.C (2003). The effect of condensed tannins on the nutrition and health of ruminants fed fresh temperate forages: a review. Anim Feed Sci Technol. 106:3-19.

Ministry of Agriculture and Land Reclamation (2008). Economic Affairs Sector, publication of livestock, different volumes. Reporter, January, 4 (1): 9-21.

Mohammed, N., N. Ajisaka, Z. A. Lila, K. Hara, K. Mikuni, S. Kanda and H. Itabashi (2004). Effect of Japanese horseradish oil on methane production and ruminal fermentation in vitro and in steers. J. of Anim. Sci., 82: 1839-1846.

Molan, A. L., G. T. Attwood, B. R. Min and W. V. McNabb (2001). The effect of condensed tannins from Lotus pendunculatus and Lotus corniculatuson on the growth of proteolytic rumen bacteria in vitro and their possible mode of action. Can. J. Micro., 47:626- 633.

Mueller-Harvey, I (2006). Unraveling the conundrum of tannins in animal nutrition and health. J. of the Sci. of Food and Agric., 86: 2010-2037.

Ngwa, A. T., I. V. Nsahlai and P. A. Iji (2002). Effect of supplementing veld hay with a dry meal or silage from pods of Acacia sieberiana with or without wheat bran on voluntary intake, digestibility, excretion of purine derivatives, nitrogen utilization, and weight gaining South African Merino sheep. Livestock Prod. Sci., 77: 253- 264.

NRC (1985). Nutrient Requirements of Domestic Animals. Nutrient Requirements of Sheep. National Research Council, Washington.D.C., USA.

Perevolotsky, A., A. Brosh, O. Ehrlich, M. Gutman, Z. Henkin and Z. Holtzer (1993). Nutritional value of common oak (Quercus calliprinos) browse as fodder for goats: Experimental results in ecological perspective. Small Rum. Res., 11: 95-106.

Raghuvansi, S. K., R. Prasad, A. S. Mishra, O. H. Chaturvedi, M. K, Tripathi, A. K. Misra, B. L Saraswat and R. C. Jakhmola (2007). Effect of inclusion of tree leaves in feed on nutrient utilization and rumen fermentation in sheep. Bio Resource Tech., 98: 511-517.

Ravindran, V. and A. Rajaguru (1988). Effect of stem pruning on Cassava root yield and leaf growth Sri Lankan J. Agri. food Chem., 37: 712-716.

Shetaewi, M. M.; A. M. Abdel-Samee and E. A. Bakr (2001). Reproductive Performance and milk production of Damascus goats fed acacia shrubs or berseem clover hay in North Sinai, Egypt. Trop. Anim. Health \& Prod., 33(1):67-79.

SAS Institute (2003). SAS/STATE User s Guide: statistics, Ver.9.1, SAS Institute Inc., Cary, NC, USA. 
Satter, L. D. and L. L. Slyter (1974).The effect of ammonia concentration on rumen microbial protein production in vitro. Br. J. Nut., 32: 199-208.

Schlegel, E. R (2015). Evaluation of ammoniated wheat straw in receiving and growing diets. M.sci. Thesis Department of Animal Sciences and Industry, College of Agriculture Kansas State University Manhattan, Kansas, USA.

Shahen, G.F., Zaki, A.A. and Yousef, H.M. (2004) Effect of feeding level on growth nutrient digestibility and feed efficiency for buffalo calves. Egyptian Journal of Nutrition Nutrition and Feeds, 7, 11.

Shahidi, F. and M. Naczk (2003). Phenolics in Food and Nutraceuticals. CRC Press, London, United Kingdom.

Silanikove, N., Z. Nitsan and A. Perevolotsky (1994). Effect of a daily supplementation of polyethylene glycol on intake and digestion of tannin-containing leaves (Ceratoniasiliqua) by sheep. J. Agr. Food Chem., 42: 2844-2847.

Ünal, N., Atasoy, F., Akçapinar, H., Koçak, S., Yakan, A., Erol, H., and Uğurlu, M. (2007). Milk yield measured by oxytocin plus hand milking and weigh-suckle-weigh methods in ewes originating from local crossbred in Turkey. Revue Méd.Vét. 158, 320-325.

Van Soest, P. J., J. B. Robertson and B. A. Lewis (1991). Methods for dietary fiber, neutral detergent fiber, and non-starch polysaccharides in relation to animal nutrition. J. Dairy Sci., 74: 3583-3597.

Waghorn, G. C (1996). Condensed tannins and nutrient absorption from the small intestine. In: Rode, L.M. (Ed.), Anim. Scie. Res. and Develop.. Proc. Canadian Soc. Anim. Sci. Annual Meeting. Lethbridge, Canada, pp. 175-194.

Wanapat, M (2000). Rumen manipulation to increase the efficient use of local feed resources and productivity of ruminants in the tropics. Asian-Aust. J. Anim. Sci., 13:59-67. 


\section{El-Gohary et al.}

دراسة تأثثر خلط النباتات الغنية بالتانينات مع تبن القمح المعامل بالأمونيا في علائق الأغنام البرقي على الهضم،الأداء وبعض مكونات الام الثبات النيوية

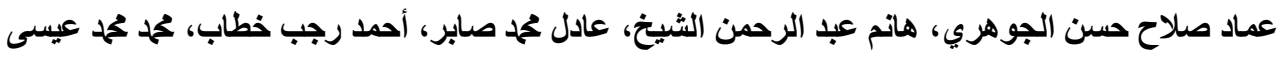

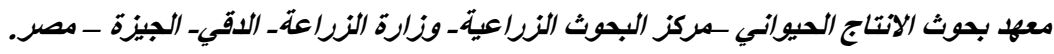

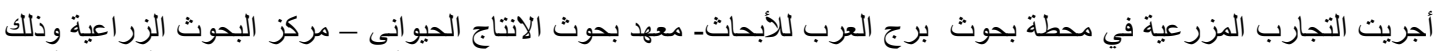

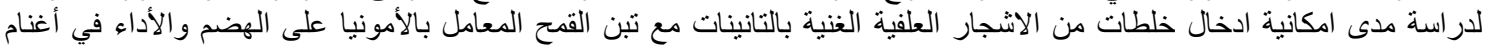

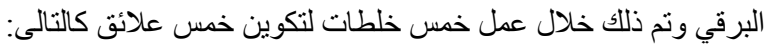

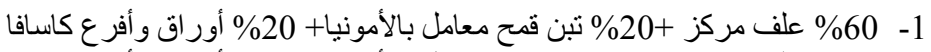

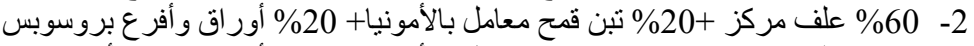

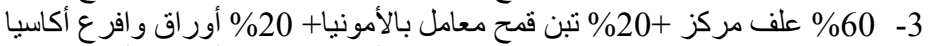

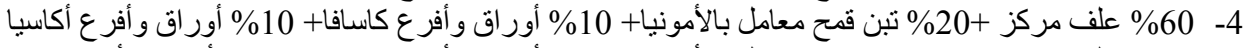

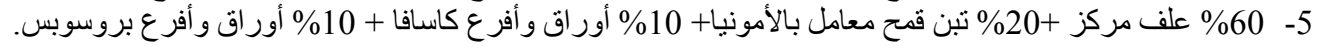
اختبرت تلاك الخلطات من خلال ثلاث تجارب:

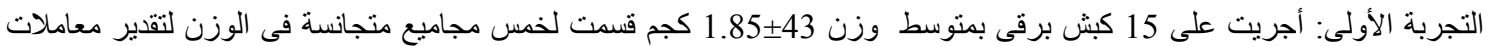

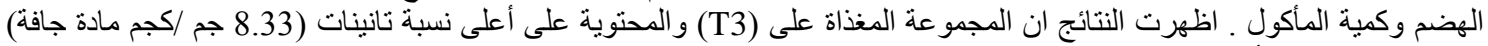

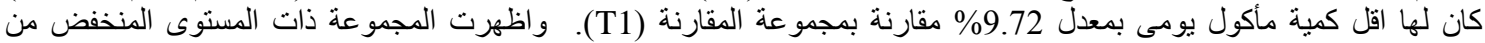

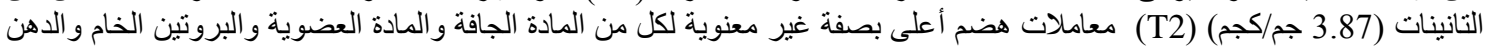

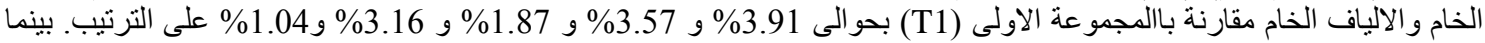

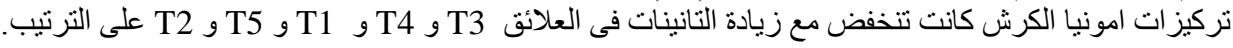

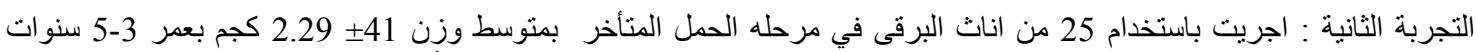

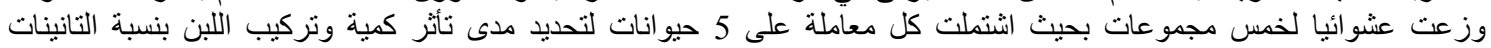

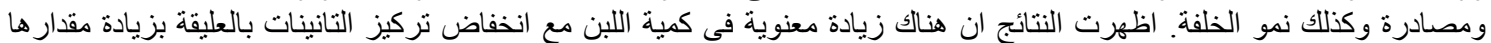

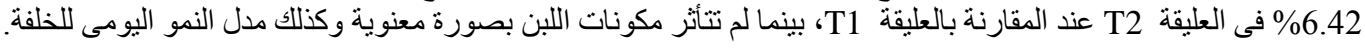

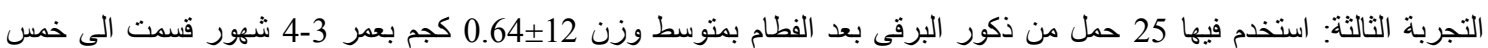

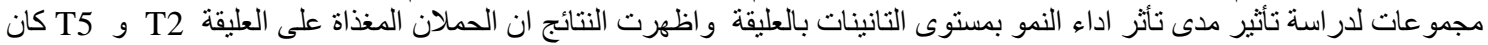

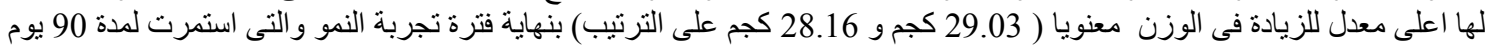

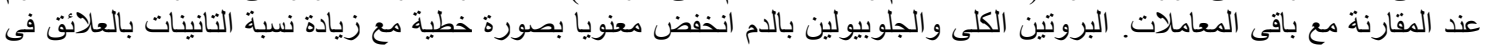

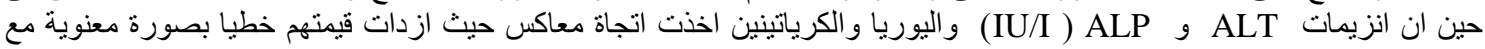
زيادة مستوى النانينات بالعليقة.

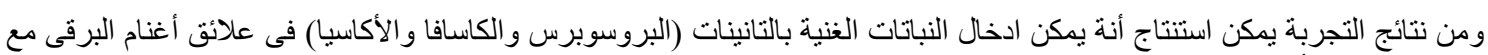

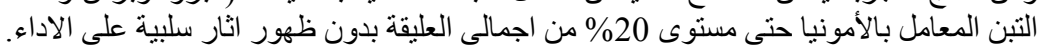

